可視化情報 Vol.21 Suppl. No.1（2００１年７月）

\title{
101 回転円盤に誘起される薄い層内流れの可視化と画像解析
}

\author{
○木澤 修一(京工䋐大院), 村田 滋(京工纎大) \\ Visualization for the thin layer flow induced \\ by a rotating disk and its image analysis
}

Shuichi KIZAWA,Shigeru MURATA

\begin{abstract}
:
In this paper, we describes the flow visualization and the image analysis results for the thin layer flow induced by a rotating disk supported by a point-contact bearing, such as a pivot bearing. The visualiation images are digitized into a personal computer to obtain velocity vectors maps using a PIV algorithm, direct cross-correlation method. The resulting velocity maps show the strong shear and unsteadiness in the thin layer.
\end{abstract}

Keyword: Rotating disk; Point-contact bearing; Thin layer

\section{1 緒言}

流れの特性を理解することは、流れが関与する回転 機械の設計や性能改善において非常に重要なことであ る。近い将来臨床応用が期待されている人工心臟にも 遠心ポンプなどの回転機械が用いられておう、血栓形 成 (血液凝固) 防止および溶血 (血球破壊) 防止、体内 埋込みのための小型化や発熱防止などの問題改善に対 する研究開発が精力的に行われている [1][2]。

本研究は、一点支持を用いた遠心ポンプのインペラ 付近の流れに関する研究を参考にしており、一点支持 された回転円盤が外壁と成す薄い流れ場に注目し、円 盤の回転によって誘起される薄い層内流れの特徴を調 べるために、可視化及び画像解析を試みた。

\section{2 観測方法}

Fig.1 は観測系の概略を示している。可視化対象とし た一点支持円盤を有する角型アクリル可視化模型を水 平に設置し、これを CCD カメラを用いて側面から観測 する。可視化模型の下方から、スリットを介して回転軸 に平行なシート光を照射し、流れ場を光切断して可視 化を行った。可視化画像はマクロレンズを使用して流
れ場を拡大して撮影し、照明には発光間隔を自由に調 節できる 2 灯式ストロボを使った。画像サイズは 640 $\times 480(0.00625 \mathrm{~mm} / \mathrm{pixel})$ であり、ノンインターレー ス画像を $0.5 \mathrm{msec}$ 間隔で撮影したものを一組とした。 回転円盤の回転数を $100 \mathrm{rpm} 、 150 \mathrm{rpm}$ とした時に光切 断面を回転軸からそれぞれ $10 \mathrm{~mm} 、 15 \mathrm{~mm} 、 20 \mathrm{~mm}$ と 変化させて観測を行った。

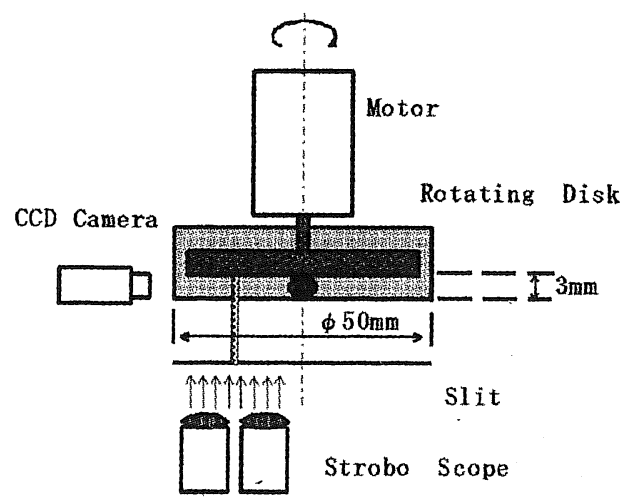

Fig. 1: Observation system

本実験で用いた観測装置は以下のとおりである。

・ CCD カメラ; SONY XC-55, B/W プログレッシ ブ型, 有効画素数 $659 \times 496$ 
・レンズ ; SONY 50mm Macro Lens, 倍率× 0.8〜 1.2 , 焦点距離 $50 \mathrm{~mm}$

- 画像入力装置; Matrox Genesis, $640 \times 480$ 画素

- 照明装置; ストロボスコープ 日進電子 CF$100 \mathrm{EW}$, 閃光時閒 $20 \mu \mathrm{sec}$

・トレーサ粒子; リルサンパウダー, 粒径 80〜200 $\mu$ $\mathrm{m}$

\section{3 計測方法}

PIVによる画像解析法として、直接濃度相関法 [3] 用いた。測定点数は $35 \times 25$ の 875 点、相関領域の大 きさは $45 \times 45$ 画素、探查領域の大きさは $90 \times 90$ 画 素とした。相互相関関数 $R$ の計算は次の式で示される ものを使用した。

$$
R=\frac{\sum_{i=1}^{n^{2}}\left\{\left(f_{i}-\bar{f}\right)\left(g_{i}-\bar{g}\right)\right\}}{\left(\sum_{i=1}^{n^{2}}\left(f_{i}-\bar{f}\right)^{2} \cdot \sum_{i=1}^{n^{2}}\left(g_{i}-\bar{g}\right)^{2}\right)^{\frac{1}{2}}}
$$

ただし、n は相関領域一辺の大きさ、 $f_{i}, g_{i}$ はそれ ぞれの画像における輝度值、 $\bar{f}, \bar{g}$ は $\mathrm{n} \times \mathrm{n}$ の領域に おける平均輝度值を表す。

また、サブピクセル処理にはガウス分布を用い、サ ブピクセル移動量 $P$ の計算には次式のものを採用して いる。ここで、 $p$ は相関ピーク值で得られる整数画素単 位の移動量、 $k$ は一次元方向のある画素位置を表す。

$$
P=p-\frac{1}{2} \frac{\log R_{k+1}-\log R_{k-1}}{\log R_{k+1}-2 \log R_{k}+\log R_{k-1}}
$$

\section{4 計測結果}

円盤回転数を $150 \mathrm{rpm}$ 、光切断面の位置を回転軸か ら $15 \mathrm{~mm}$ とした時における結果を示す。円盤外壁の周 速度を代表速度、円盤と外壁との間隔を代表長さとし た時のレイノルズ数は 1178 である。Fig.2 は可視化画 像の一例、Fig. 3 は瞬間速度べクトル、Fig.4 は処理画 像組数 75 組に対する時間平均速度ベクトル図である。 時間平均速度ベクトル図からは回転円盤に引きずられ る方向にクエット流に似た流れが生じており、強いせ ん断が誘起されていることが分かる。一方、瞬間速度 ベクトル図では流れの中に明らかに空間的な速度変動 成分が存在することが確認できる。

\section{5 結言}

一点支持された回転円盤によって誘起される薄い層 内の流れを側面から捉え、可視化および画像解析の結
果を示した。回転円盤によって誘起される流れは、時 間平均的には、クエット流のような滑らかな速度勾配 をもっているが、一方では、時間変動成分をもつ空間 的な渦構造も観測できた。

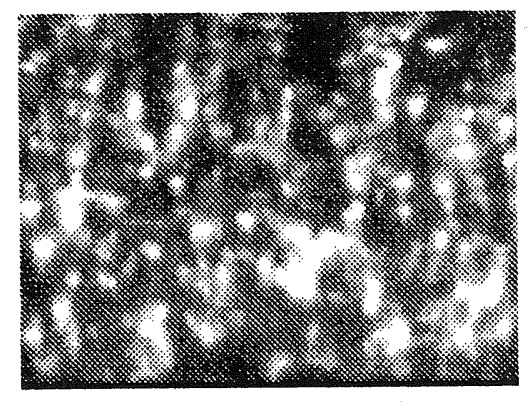

Fig. 2: A visualization image

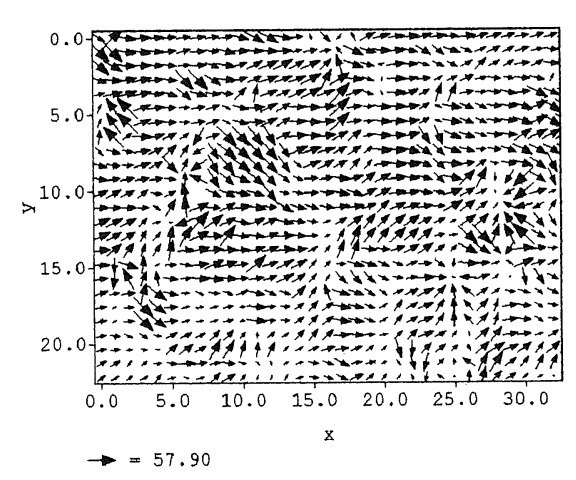

Fig. 3: A simultaneous velocity vector map

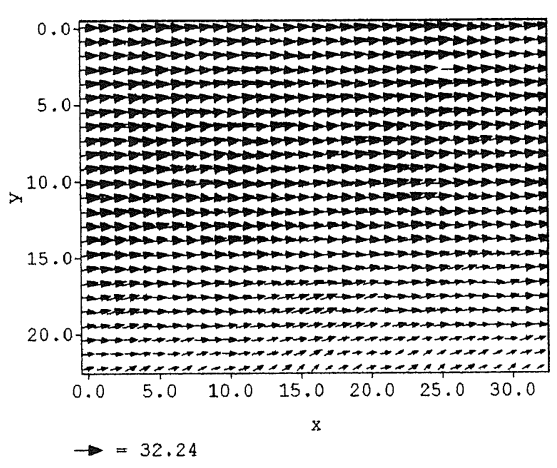

Fig. 4: A time-averaged velocity vector map

\section{参考文献}

[1] 築谷朋典, 赤松映明: 磁気浮上式遠心血液ポンプの開発, 日本機 械学会論文集 (B 編),Vol.61, No.591(1995),pp.3913-3920.

[2] 山根隆志：人工心臟の開発と動向，日本産業技術振興協会技術 資料 No.280(1998)，pp.62-74.

[3] 西尾茂: ここが違う PIV の原理実践講義 PIV の要点, 可視 化情報学会講習会テキスト, VSJ-PIV-S1(1998), pp.15-25. 